Chapter 1

\title{
BIOLOGIC THERAPIES FOR SYSTEMIC LUPUS ERYTHEMATOSUS
}

\author{
Maria Mouyis ${ }^{1}$, MBBS MRCP, \\ Coziana Ciurtin ${ }^{2,3}$, MBBS MSc PhD, \\ and David Isenberg ${ }^{2,3, *}$ MD FRCP FAMS \\ ${ }^{1}$ Department of Rheumatology, Northwick Park Hospital, London, UK \\ ${ }^{2}$ Department of Rheumatology, University College London Hospital \\ NHS Foundation Trust, London, UK \\ ${ }^{3}$ Centre for Rheumatology, Department of Medicine, \\ University College London, London, UK
}

\begin{abstract}
Advances in molecular biology have led to the development of biologic therapies. This is particularly relevant in systemic lupus erythematosus (SLE), which is a multisystem autoimmune rheumatic disease (ARD) associated with potentially life-threatening complications if not adequately treated. The availability of new biologic drugs has improved the prognosis of SLE in selected cases associated with
\end{abstract}

\footnotetext{
* Correspondence to: Prof. David A Isenberg, Academic Director of Rheumatology, Centre for Rheumatology, 424 The Rayne Institute, 5 University Street, University College London, London, WC1E 6JF, UK, email: d.isenberg@ucl.ac.uk
} 
unsatisfactory response to conventional therapies. Over the last decade, there have been developments in the availability of biologic agents for SLE treatment based upon the advances in the understanding of the disease pathogenesis. Even if the evidence of biologic treatment efficacy in SLE is weaker than in other autoimmune rheumatic diseases, such as rheumatoid arthritis (RA), significant progress was made, as the first biologic treatment for use in SLE patients received approval in 2011. These new biologic therapies for SLE range from anti-CD20/CD22 (clusters of differentiation characteristic to $\mathrm{B}$ cells), to anti-B cell activating factors and antiinterferon alpha (IFN $\alpha$ ). This chapter reviews the various biologic agents used in SLE, their mechanism of action and safety profile. The most common side effects to biologic treatments include infection, tuberculosis (TB) reactivation and allergic reactions. Less common side effects include development of lymphoma and anti-drug or autoimmune antibody formation. Despite their toxicity profile, biologic agents are gaining ground in clinical practice, due to the limited efficacy or increased toxicity of conventional disease modifying agents (DMARDs). Biologic therapies targeting B cells, such as rituximab, and B cell activation factors, such as belimumab, are currently used in the treatment of refractory SLE. Furthermore, aggressive treatment, including the use of biologic agents, reduces long-term complications associated with prolonged use of steroids in SLE, such as cardiovascular disease and osteoporosis. In the short term, the biologic agents are expensive when compared to traditional DMARDs; however there is evidence that their use is associated with long term benefits for patients with SLE, such as reduced hospital admission and disease complications, and improved patient outcomes. This chapter provides a summary of most biologic agents tested in SLE patients, considering their efficacy and safety profile, as well as the health implications associated with their use. We also take a brief look at newer agents currently investigated in clinical trials.

Keywords: systemic lupus erythematosus, biologic treatments, safety, efficacy, biosimilars.

\section{INTRODUCTION}

SLE is a complex ARD characterised by clinical manifestations that range from mild to severe. For many years the main treatments used were the traditional DMARDs, such as hydroxycholorquine, azathioprine, cyclophosphamide, methotrexate and mycophenolate mofetil (MMF). Unfortunately, these therapeutic agents have increased toxicity or, in some cases, limited efficacy in controlling the complex symptoms of this disease. 
Despite the progress made in optimising the treatment of severe disease manifestations (e.g., lupus nephritis), the long-term prognosis of this disease has not changed dramatically in the last 30 years [1]. Patients with SLE are often treated for many years with prednisolone, which provides an additional array of complications, such as hypertension, glaucoma, steroid induced diabetes and osteoporosis. Although the treatment of SLE has, on the whole, improved lupus outcomes, less success was achieved in preventing or addressing the increased morbidity of this condition [2-4]. The availability of biologic agents is leading to a new treatment era for SLE patients, and there is hope for a better therapeutic management in the future.

\section{Pathogenesis}

A deeper understanding of the pathogenesis of SLE facilitated the discovery and development of many biologic agents targeting various molecules or receptors [5]. The correlation between different cellular and molecular players identified as key factors in lupus pathogenesis, and the available biologic therapies targeting the abnormalities associated with lupus, are illustrated in Figure 1. SLE is largely a B cell driven phenomenon with interplay between genetic, hormonal and environmental factors [6]. External triggers, such as ultraviolet (UV) radiation or Ebstein-Barr virus (EBV) infection, in conjunction with a maladaptive immune system and altered epigenetics are known to lead to the accumulation of apoptotic nuclear debris comprising anti-double stranded DNA (dsDNA) fragments and RNA antigens [7-9]. The debris is then processed by B cells, which function as antigen presenting cells (APC). This process then precipitates the formation of antibody production, and the release of proinflammatory cytokines such as interleukin (IL) 6, IL10, interferon $\gamma$ (IFN $\gamma$ ), B lymphocytes stimulator/a proliferation-inducing ligand (BLyS/APRIL) and tumour necrosis factor alpha (TNF $\alpha)$. These cytokines promote auto B cell and auto $\mathrm{T}$ cell activation leading to a sustained inflammatory response [10].

$\mathrm{T}$ cells are important in the homeostatic control of the B cell responses. In SLE patients T cells are dysregulated. T1 helper cells are overexpressed and release significant amounts of IL12, IL18 and IFN $\gamma$. T2 helper cells are not overexpressed in comparison to T1 helper cells, but they secrete increased IL10 levels [11, 12]. There is also a decreased production in IL2 levels [13]. Regulatory $\mathrm{T}$ cells (Tregs), which are meant to dampen the pro-inflammatory $\mathrm{T}$ cell profile, are suppressed in SLE [14]. 


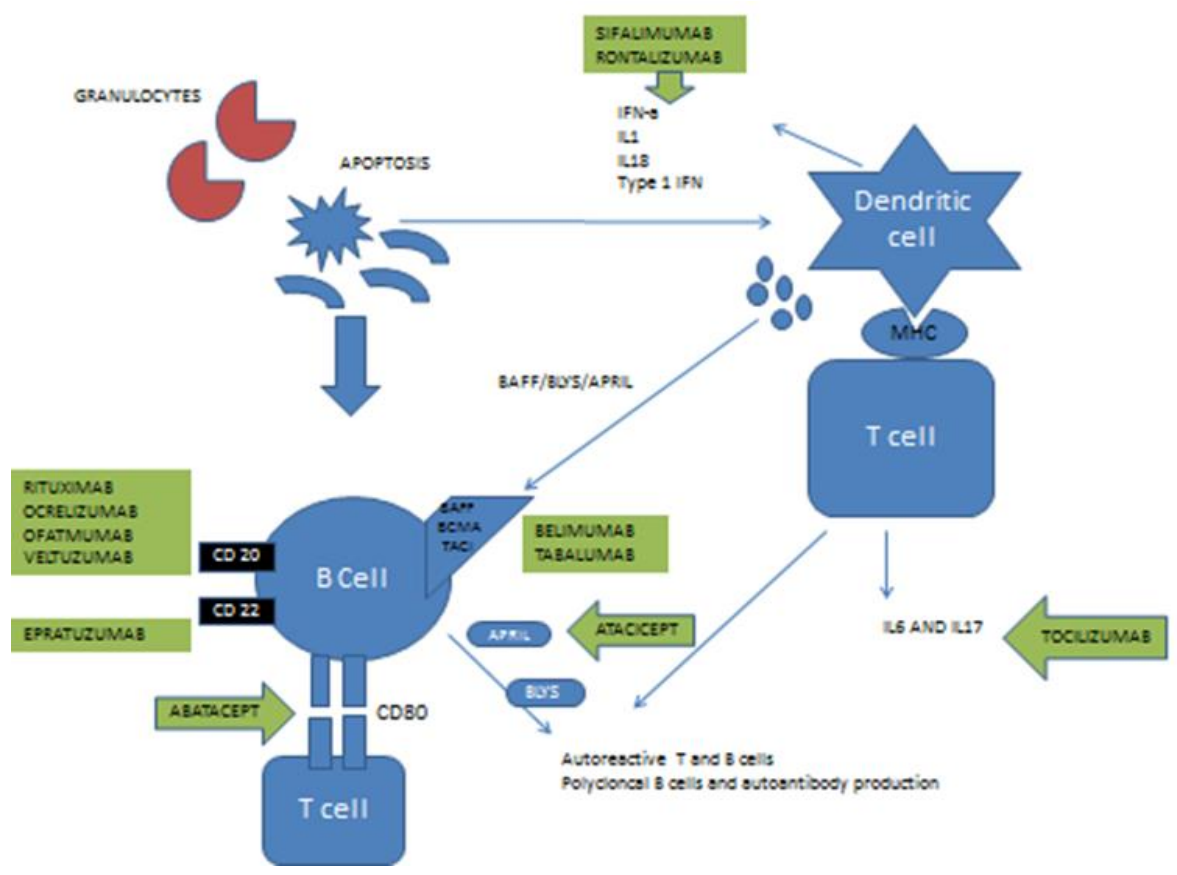

Legend: APRIL - a proliferation-inducing ligand; $B A F F$ - B cell activating factor; BlyS - B lymphocytes stimulator; CD20 - cluster of differentiation 20 marker expressed from late pro-B cells through memory cells, but not on either early pro-B cells or plasma blasts and plasma cells; CD22 - cluster of differentiation 22 found on the surface of mature B cells and to a lesser extent on some immature B cells; CD80 cluster of differentiation 80 is a protein found on activated B cells and monocytes that provides a costimulatory signal necessary for $\mathrm{T}$ cell activation and survival; IL - interleukin.

Figure 1. Schematic presentation of targeted therapy of SLE.

Furthermore there are changes in signalling subunits on the $\mathrm{T}$ cell receptors which lead to an increase production of co-stimulatory molecules such as cluster of differentiation 40 ligand (CD40L) [15]. The role of T cells in SLE is still being researched and new target biologic therapies are currently explored.

Another pathogenic process associated with lupus is the formation and deposition of immune complexes [16]. In SLE there is a failure of clearing immune complexes leading to immune complex deposition in organs such as kidneys or blood vessels, causing inflammation and tissue injury [17]. 
Every aspect of the immune abnormalities associated with lupus can be theoretically explored for therapeutic purposes. Progress has been achieved in testing different experimental biologic drugs. Recently, belimumab, an anti B cell activating factor (BAFF) therapy, became the first biologic treatment ever approved by Food and Drug Administration agency (FDA) for use in SLE patients, and the only treatment for lupus approved in over 50 years. It has also been approved for use in SLE patients in Europe, Middle East and Africa. Despite the impressive advances in molecular biology and drug technology, this complex autoimmune disease is still associated with increased morbidity and mortality. New treatment options are continuously explored to address the unmet need of a better quality of life and outcomes for patients (Figure 1).

\section{Biologic THERAPIES}

The biologic therapies, currently in use or under development for lupus target B cells, T cells, IFNa, IL6, and fusion proteins. This chapter explores the main biologic therapies available for the treatment of SLE patients, including the agents currently under investigation, detailing their mechanism of action, side effects and dosages. The level of evidence of efficacy and safety related to the efficacy of these biologic agents is summarised in Table 1.

\section{Advantages and Disadvantages}

The advantages of biologic therapies compared with some of the conventional therapies used for moderate-severe manifestations of SLE include potential efficacy in terms of disease control and relative safety in pregnancy, especially when compared to methotrexate, MMF and cyclophosphamide, which are contraindicated in pregnancy. The biggest disadvantage of both, biologic and non-biologic DMARDs, is that of immunosuppression, which is associated with increased risk of infection. Patients treated with biologics have to be screened for TB and hepatitis, as both infections can reactivate during the biologic therapy administration. A more significant concern, with most biologic agents, is the risk of progressive multifocal leukoencephalopathy (PML). This is not a drug specific phenomenon; although extremely rare, it is associated with significant mortality [18].

Another concern is that of the cost of biologic therapies. Biological agents are expensive as they are manufactured through advanced processes of 
biotechnology and genetic engineering. However, the cost of treatment needs to be compared to the cost of having to manage all the challenging aspects of the disease. SLE patients in general utilise more health resources according to the severity of their disease and age at diagnosis, and patients with active lupus nephritis or regular flares even more so than a patient with mild or quiescent disease [19-21].

The cost of a patient having SLE includes direct and indirect costs [22]. The indirect costs are related to an individual's quality of life and ability to work [23]. The cost of an individual's loss of work on average in the US is was estimated at approximatively $\$ 16,345$ per year in 2011 [19]. About 10 years ago, direct costs were assessed in a tri-nation study, which evaluated patients with SLE from several tertiary centres in Canada, US and UK respectively [24]. The direct cost of lupus treatment, including productivity over a 1 year period, was approximately $\$ 20,000$ in the US [24]. There were also significant differences of the health system indirect costs in different countries [25, 26], and differences in the access of patients with lupus to the health care system across the world $[27,28]$. A study from 2008 estimated that the annual (direct and productivity) cost for patients with lupus of employment age was \$20,924 [23]. The cost of rituximab is approximately $£ 4000$ for two infusions in the UK, and there are data suggesting the cost-saving potential of rituximab in the management of lupus nephritis [29]. With the advent of biosimilars, the cost of treating SLE may become cheaper, but the efficacy of biosimilars (arguably having similar properties to the "original" biologic treatment) has yet to be proven [30, 31]. In the context of discussing the cost-effectiveness of biologic treatments it is worth mentioning that another advantage of the use of biologic agents is the intravenous (IV) administration of some of the available agents, which improves patient compliance and adherence to medication. New therapies, such as atacicept are already available as subcutaneous (SC) injections; therefore the above advantage might be lost for some of biologic therapeutic options. On the other hand, preserving the patient independence and enabling them to selfadminister injectable treatments can contribute in itself to the reduction of additional health care costs. A study from 1991 by Petri et al. reported poorer adherence amongst Afro-Caribbean patients leading to more significant renal SLE and indirect increase in the healthcare costs [32]. Ultimately the cost of treatment needs to be balanced against the economic cost of disease for a realistic estimate of the cost-efficacy of different biologic therapeutic options. 
Table 1. An overview of biologic therapy in SLE

\begin{tabular}{|c|c|c|c|c|c|}
\hline $\begin{array}{l}\text { Biologic } \\
\text { Agent }\end{array}$ & Trial & Mechanism of action & Side effects & Dosage & $\begin{array}{l}\text { Organ specific } \\
\text { indication }\end{array}$ \\
\hline \multicolumn{6}{|c|}{ B-cell depleting agents: } \\
\hline Rituximab & $\begin{array}{l}\text { Explorer } \\
\text { Lunar }\end{array}$ & $\begin{array}{l}\text { Anti-CD20 chimeric } \\
\text { monoclonal antibody }\end{array}$ & \begin{tabular}{|l} 
Infusion reaction \\
Increased infection risk \\
PML \\
Lymphoma
\end{tabular} & $\begin{array}{l}1 \mathrm{~g} \text { IV twice, } 2 \text { weeks } \\
\text { apart } \\
375 \mathrm{mg} / \mathrm{m}^{2} \mathrm{IV} \text { every } 4 \text { weeks } \\
750 \mathrm{mg} \text { cyclophosphamide may } \\
\text { be given with the first infusion to } \\
\text { increase B cell depletion effect }\end{array}$ & $\begin{array}{l}\text { SLE nephritis } \\
\text { Non-renal SLE } \\
\text { (despite negative } \\
\text { RCTs results) }\end{array}$ \\
\hline Ofatumumab & $\begin{array}{l}\text { RA trials. } \\
\text { Case reports } \\
\text { in SLE. }\end{array}$ & $\begin{array}{l}\text { Fully human monoclonal } \\
\text { antibody against } \\
\text { membrane proximal } \\
\text { epitope on CD20 } \\
\text { molecule }\end{array}$ & \begin{tabular}{|l|} 
Infusion reactions \\
Urticaria \\
Rash \\
Rhinitis \\
Nausea \\
URTI \\
Headaches \\
Fatigue \\
Flushing \\
\end{tabular} & $\begin{array}{l}300,700,1000 \mathrm{mg} \text { IV every } 2 \\
\text { weeks for } 24 \text { weeks. }\end{array}$ & $\begin{array}{l}\text { Arthritis (RA) } \\
\text { ?SLE }\end{array}$ \\
\hline Ocrelizumab & $\begin{array}{l}\text { Phase III trials } \\
\text { in SLE }\end{array}$ & $\begin{array}{l}\text { Fully human monoclonal } \\
\text { antibody against CD20 }\end{array}$ & $\begin{array}{l}\text { Severe infections } \\
\text { (increased in patients } \\
\text { treated with MMF) }\end{array}$ & $\begin{array}{l}400 \mathrm{mg} \text { or } 1,000 \mathrm{mg} \\
\text { ocrelizumab, given as an IV } \\
\text { infusion on days } 1 \text { and } 15, \\
\text { followed by a single infusion at } \\
\text { week } 16 \text { and every } 16 \text { weeks } \\
\text { thereafter }\end{array}$ & SLE nephritis \\
\hline
\end{tabular}


Table 1. (Continued)

\begin{tabular}{|c|c|c|c|c|c|}
\hline $\begin{array}{l}\text { Biologic } \\
\text { Agent }\end{array}$ & Trial & Mechanism of action & Side effects & Dosage & $\begin{array}{l}\text { Organ specific } \\
\text { indication }\end{array}$ \\
\hline \multicolumn{6}{|c|}{ Anti-B-cell activating factors } \\
\hline Epratuzumab & $\begin{array}{l}\text { EMBODY-1 } \\
\text { EMBODY-2 }\end{array}$ & $\begin{array}{l}\text { IgG1 monoclonal antibody } \\
\text { against the CD22 } \\
\text { molecule }\end{array}$ & $\begin{array}{l}\text { Infusion reaction, } \\
\text { URTI's Fever } \\
\text { Headache } \\
\text { Nausea and dizziness }\end{array}$ & $\begin{array}{l}600 \mathrm{mg} \text { IV every week for } \\
\text { four weeks or } 1,200 \mathrm{mg} \text { IV } \\
\text { every two weeks for four } \\
\text { weeks }\end{array}$ & $\begin{array}{l}\text { Neuro-psychiatric, } \\
\text { muco-cutaneous and } \\
\text { musculoskeletal SLE } \\
\text { manifestations. }\end{array}$ \\
\hline Belilumab & $\begin{array}{l}\text { BLISS } 52 \\
\text { BLISS } 76\end{array}$ & $\begin{array}{l}\text { Human monoclonal } \\
\text { immunoglobulin (IgG1y) } \\
\text { against BAFF/BLySS. }\end{array}$ & $\begin{array}{l}\text { Nausea } \\
\text { Diarrhoea } \\
\text { Headaches } \\
\text { URTI } \\
\text { Fever } \\
\text { Cystitis } \\
\text { Infusion reaction } \\
\end{array}$ & $\begin{array}{l}10 \mathrm{mg} / \mathrm{kg} \text { IV every } 2 \\
\text { weeks x } 3 \text { and then once } \\
\text { every } 4 \text { weeks }\end{array}$ & $\begin{array}{l}\text { Non renal SLE } \\
\text { Non cerebral SLE }\end{array}$ \\
\hline Tabalumab & IILUMINATE & $\begin{array}{l}\text { Human monoclonal } \\
\text { antibody against BAFF }\end{array}$ & \begin{tabular}{|l|} 
URTI \\
UTI \\
Injection site reactions \\
Myocardial infarct \\
Discitis \\
Osteomyelitis \\
Breast cancer \\
Cerebrovascular accident \\
Pulmonary fibrosis \\
\end{tabular} & $\begin{array}{l}240 \mathrm{mg} \text { SC loading dose, } \\
\text { followed by } 120 \mathrm{mg} \text { SC } \\
\text { every } 2 \text { or } 4 \text { weeks }\end{array}$ & $\begin{array}{l}\text { Non-renal SLE } \\
\text { Non-cerebral SLE }\end{array}$ \\
\hline Blisibimod & $\begin{array}{l}\text { Phase II } \\
\text { PEARL-SC }\end{array}$ & $\begin{array}{l}\text { Fusion protein, selective } \\
\text { antagonist of BAFF }\end{array}$ & Injection site reactions & 200 mg SC weekly & \begin{tabular}{|l} 
Non-renal SLE \\
Non-cerebral SLE
\end{tabular} \\
\hline
\end{tabular}




\begin{tabular}{|c|c|c|c|c|c|}
\hline $\begin{array}{l}\text { Biologic } \\
\text { Agent }\end{array}$ & Trial & Mechanism of action & Side effects & Dosage & $\begin{array}{l}\text { Organ specific } \\
\text { indication }\end{array}$ \\
\hline Atacicept & $\begin{array}{l}\text { Phase II APRIL- } \\
\text { SLE (terminated) } \\
\text { Phase II } \\
\text { ADDRESS-II } \\
\text { (ongoing) }\end{array}$ & $\begin{array}{l}\text { TACI-Ig fusion protein that } \\
\text { inhibits BLyS and APRIL }\end{array}$ & $\begin{array}{l}\text { LRTI/URTI } \\
\text { Injection site reaction } \\
\text { Fever } \\
\text { Arthralgia } \\
\text { Sinusitis } \\
\text { Headache } \\
\text { Fatigue } \\
\text { Rhinitis } \\
\text { Dizziness } \\
\text { Depression }\end{array}$ & $\begin{array}{l}75 \mathrm{mg} \text { or } 150 \mathrm{mg} \mathrm{SC} \\
\text { weekly }\end{array}$ & $\begin{array}{l}\text { SLE nephritis-study } \\
\text { terminated because of } \\
\text { side-effects. }\end{array}$ \\
\hline \multicolumn{6}{|c|}{ Anti-IFN alpha } \\
\hline Sifalimumab & Phase III trial & IFN $\alpha$ monoclonal antibody & $\begin{array}{l}\text { Infusion reaction } \\
\text { Fatigue } \\
\text { URTI } \\
\text { UTI } \\
\text { Sinusitis } \\
\text { Dizziness } \\
\text { Arthralgia } \\
\text { Headache } \\
\text { Lymphopenia } \\
\text { Anaemia }\end{array}$ & $\begin{array}{l}0.3,1.0,3.0, \text { or } 10.0 \\
\mathrm{mg} / \mathrm{kg} \text { IV- still } \\
\text { undergoing trials }\end{array}$ & SLE nephritis \\
\hline Rontalizumab & Phase II trial & $\begin{array}{l}\text { A recombinant humanized } \\
\text { monoclonal antibody to } \\
\text { IFN } \alpha\end{array}$ & $\begin{array}{l}\text { Viral infections } \\
\text { Reactivation of Herpes } \\
\text { infection } \\
\text { Sinusitis } \\
\text { Bronchitis }\end{array}$ & $\begin{array}{l}750 \mathrm{mg} \text { IV } 4 \text { weekly } \\
300 \mathrm{mg} \text { SC } 2 \text { weekly } \\
0.3-10 \mathrm{mg} / \mathrm{kg}\end{array}$ & Moderate-severe SLE \\
\hline
\end{tabular}


Table 1. (Continued)

\begin{tabular}{|c|c|c|c|c|c|}
\hline $\begin{array}{l}\text { Biologic } \\
\text { Agent }\end{array}$ & Trial & Mechanism of action & Side effects & Dosage & $\begin{array}{l}\text { Organ specific } \\
\text { indication }\end{array}$ \\
\hline Anifrolumab & Phase II trial & $\begin{array}{l}\text { A type I IFN receptor } \\
\text { antagonist }\end{array}$ & $\begin{array}{l}\text { Influenza } \\
\text { Herpes-Zoster }\end{array}$ & $\begin{array}{l}300 \mathrm{mg} \text { IV monthly } \\
1000 \mathrm{mg} \text { IV monthly }\end{array}$ & Moderate-severe SLE \\
\hline \multicolumn{6}{|c|}{ Blockade of T cell activation } \\
\hline Abatacept & Phase III trials & $\begin{array}{l}\text { Human IgG1 heavy chain } \\
\text { fused with CTLA4 that } \\
\text { blocks T cell activation by } \\
\text { B cells. }\end{array}$ & \begin{tabular}{|l} 
Nausea \\
Headache, \\
Infusion reaction \\
Fever \\
Hypertension, \\
Back pain Infections
\end{tabular} & $10-30 \mathrm{mg} / \mathrm{kg} \mathrm{IV}$ & $\begin{array}{l}\text { Discoid SLE } \\
\text { Arthritis, } \\
\text { Serositis }\end{array}$ \\
\hline \multicolumn{6}{|l|}{ IL6 inhibition } \\
\hline Tocilizumab & $\begin{array}{l}\text { RA trials } \\
\text { Phase } 1 \text { SLE } \\
\text { trials }\end{array}$ & $\begin{array}{l}\text { Monoclonal IgG1 } \\
\text { antibody to IL6 receptor }\end{array}$ & \begin{tabular}{|l} 
URTI \\
GI infections \\
TB \\
GI perforation \\
Non-melanoma skin tumours \\
Malignancies \\
Abnormal LFT \\
High cholesterol levels \\
Suppression of CRP
\end{tabular} & 4 or $8 \mathrm{mg} / \mathrm{kg} \mathrm{IV}$ & $\begin{array}{l}\text { SLE nephritis } \\
\text { SLE with moderate } \\
\text { activity }\end{array}$ \\
\hline
\end{tabular}

Legend: CRP - C reactive protein; CTLA4 - cytotoxic T-lymphocyte-associated protein 4; GI - gastro-intestinal; IFR - individual funding request form, IFN - interferon; Ig - immunoglobulin; IL - interleukin; IV - intravenous; LFT - liver function tests; LRTI - lower respiratory tract infection; MMF mycophenolate mofetil; PML - progressive multifocal leukoencephalopathy; RA - rheumatoid arthritis; RCT - randomized controlled trial; SC subcutaneous, SLE - systemic lupus erythematosus; TB - tuberculosis; URTI - upper respiratory tract infection; UTI - urinary tract infection. 
The use of biologic agents in different countries is highly variable. In countries with poorer economic status, the access to expensive treatment options is limited and not always fairly distributed in the population. Mortality in lupus was associated with lower education, shorter duration of follow up and poor medical coverage in a large study from South American countries [33].

Belimumab is licensed for use to treat SLE in the US, Europe, but in the $\mathrm{UK}$, the funding of the treatment is based on an individual funding request (IFR). The disparity between the outcome of patients with lupus nephritis with private vs. public health insurance in US is well recognised [27, 34].

Belimumab has not been approved by NICE (National Institute of Clinical Excellence) who do not consider it cost-effective as assessed by QALY (qualityadjusted life year) calculations; although real life experience shows some clinical benefits in patients with skin and joint manifestations [35]. Arguably QALY, which aims to appreciate the disease burden by taking into consideration both, the quality and duration of life, is a flawed measurement tool in the healthcare system [36]. An ideal system treatment for SLE would ensure an increased good quality life span at the lowest possible health care cost. This challenge is compounded by the dilemma of using biosimilars, which supposedly have similar efficacy as the biologic agents and the advantage of lower cost. However, data regarding the efficacy of biosimilars in head-to-head clinical trials aiming to compare them with the original biologic agent are missing for the majority of available options.

Table 1 summarises the most studied biologic treatments in patients with lupus, with particular emphasis on their efficacy for certain SLE manifestations, dosage and toxicity profile.

\section{Biologic Therapies Affecting B Cells}

1. Anti-CD20 - rituximab, ofatumumab, ocrelizumab, veltuzumab

2. Anti-CD22 - epratuzumab

\section{Rituximab}

\section{Mechanism of Action and Dosage}

Rituximab is a chimeric/humanised monoclonal antibody against CD20. It was the first biologic to be used in the treatment of SLE. The drug depletes CD20 B lymphocytes. The CD20 antigen is found on pre - B cells which would then form mature B cells [37]. Depletion of the B cell therefore reduces cell apoptosis and complement activation [38, 39]. Although the function of CD20 is unknown, it is considered that it may play a role in $\mathrm{Ca}^{2+}$ influx across plasma 
membranes, maintaining intracellular $\mathrm{Ca}^{2+}$ concentration and allowing differentiation and activation of B cells.

The fragment antigen binding ( $\mathrm{Fab}$ ) domain of rituximab binds to the CD20 antigen on $\mathrm{B}$ lymphocytes, and the fragment crystallisable $(\mathrm{Fc})$ domain recruits immune effector functions to mediate $\mathrm{B}$ cell lysis in vitro; in addition rituximab increases the expression of major histocompatibility complex II (MHC II), and lymphocyte function-associated antigens 1 and 3 (LFA-1, LFA-3), triggers shedding of CD23, down-regulates $\mathrm{B}$ cell receptor and induces the apoptosis of CD20 B cells [40].

The standard dose currently recommended for the treatment of SLE is $1 \mathrm{~g}$ of IV rituximab given 2 weeks apart. Each dose is preceded by premedication with methylprednisolone, antihistamine and paracetamol to reduce the risk of infusion reactions. Cyclophosphamide may also be given pre-first dose to increase the efficacy of rituximab and enhance B cell depletion [41].

\section{Efficacy and Side Effect Profile}

Rituximab is considered effective in treating refractory SLE, although two large trials, LUNAR (clinical trial of patients with lupus nephritis) and EXPLORER (clinical trial which included non-renal patients) did not meet their primary endpoints. The reason for this is likely related to the concomitant use of high dose of steroids and concomitant conventional immunosuppressant therapy [42, 43]. However, some significant clinical and serological results were noted (e.g., significant reduction in proteinuria, lower steroid requirement, etc.). Despite the failure of these clinical trials, numerous case-reports and studies using rituximab off-label in lupus patients have shown a 70-90\% response rate [43-46]. The role of Rituximab as a steroid sparing agent has also become evident. Condon et al. reported results on 50 lupus nephritis patients treated with $1 \mathrm{~g}$ of rituximab 2 weeks apart and $500 \mathrm{mg}$ of IV methylprednisolone [47]. No oral steroids were given and MMF was used as maintenance therapy. $70 \%$ ( $\mathrm{n}=$ 36) of the patients achieved remission in a mean time of 36 weeks. The conclusion of the researchers was that oral steroids can be avoided (only 2/50 patients required them in a 2 year follow up period), and B cell depletion might be considered early in the treatment of lupus nephritis and other systemic manifestations of SLE. Rituximab minimized the need for additional steroids and was effective in ensuring a better long term control of the disease. An earlier, albeit smaller study of eight newly diagnosed rituximab treated patients (each case carefully matched to three conservatively treated patients) reported similar steroid sparing capacity of rituximab in non-renal lupus patients [48]. An international trial comparing rituximab and MMF in lupus nephritis patients 
treated with minimal dose of steroids vs. standard therapy with high doses of steroids and MMF (the RITUXILUP study) is currently undergoing and should provide more definitive answers regarding the exciting possibility to treat patients with lupus with low doses of steroids and rituximab.

Side-effects of rituximab include infusion reactions as documented in the initial oncology studies [49]. The most common side-effects are fever, bronchospasm, rash and hypotension, which usually settle on stopping the infusion. Patients are usually followed up carefully post-rituximab treatment to monitor for the development of common bacterial and viral infections, or other infections, such as TB and hepatitis B or C. Based on the experience acquired from treating RA patients with rituximab, this biologic agent is considered reasonably safe in the context of history of TB [50, 51]. There are reports of both reactivation of hepatitis B following treatment with rituximab [52], as well as effective treatment of vasculitis associated with hepatitis $C$ with rituximab [53, 54]. Human anti chimeric antibodies have also been reported [55], and sideeffects to medication are considered to be linked to the immunogenicity of these antibodies [56]. The effect of B cell depletion lasts for 6-12 months in about $75 \%$ of cases, and the response to therapy is variable $[38,57,58]$, and, as shown recently, the longer the duration of $B$ cell depletion, the better the outcome [59]. The process of B cell repopulation following B cell depletion therapy with rituximab in lupus is still not fully understood [60]. For safety reasons, it is recommended to check immunoglobulin (Ig) levels and CD19+ B cell count every 2 months until B cells normalise, as accumulated doses of rituximab may also cause hypogammaglobulinaemia which may be linked to an increased the risk of infection [61, 62].

The expert consensus is that rituximab is a safe and effective treatment option for patients with refractory renal and non-renal lupus and can reduce significantly the steroid burden [48, 63-65], despite the negative trial results.

\section{Ofatumumab}

\section{Mechanism of Action and Dosage}

Ofatumumab is a fully human monoclonal antibody anti-CD20 [66]. The treatment is licensed for use in patients with chronic lymphocytic leukaemia based on its proven efficacy in treating refractory cases [67, 68]. Most studies assessing dosing regimens in patients with rheumatic conditions have been done in RA patients, in whom the treatment was also associated with clinical benefit $[69,70]$. The current recommended dose is $700 \mathrm{mg}$ IV every 2 weeks. Similarly 
with other biologic agents, premedication is administered beforehand, to minimise the risk of infusion reactions [71].

Efficacy and Side Effect Profile

The safety profile and efficacy of ofatumumab has also been established in a few RA clinical trials $[69,71]$. The drug has been proved effective as B cell depletion agents as was associated with significant clinical improvement of symptoms of arthritis at different doses [71]. The pharmacokinetic of the medication was found similar in chronic lymphocytic leukaemia and RA [72]. A recent case report has suggested some benefit in the treatment of SLE [73].

Although safety profiles were established in phase 1 and II trials, the most comprehensive information related to the drug's safety profile was provided by a phase III clinical trial in RA [69]. The most common side-effects were rash (21\%) and urticaria (12\%), which mostly occurred on the day of first infusion and they declined significantly with the second course. Most adverse events were of mild or moderate intensity (see Table 1).

\section{Ocrelizumab}

\section{Mechanism of Action and Dosage}

Ocrelizumab is another fully human monoclonal antibody against CD20, developed for RA, SLE, and B cell derived malignancies [74, 75], which was tested for efficacy in patients with lupus nephritis [76]. The doses used in the largest phase III clinical trial were $400 \mathrm{mg}$ or $1,000 \mathrm{mg}$ ocrelizumab, given as an IV infusion on days 1 and 15, followed by a single infusion at week 16 and every 16 weeks thereafter [76].

\section{Efficacy and Side Effect Profile}

Despite reaching an overall response rate of $66-67 \%$ in the ocrelizumab treatment arm, the difference in response vs. standard of care treatment did not reach statistical significance [76]. The study was terminated earlier as there was an infection-related safety signal in relation with increased risk of opportunistic and fatal infections in the ocrelizumab treatment groups [77]. The proportion of patients experiencing serious infections was twice as high in patients who received concomitant treatment with MMF (32\% vs. $16 \%$ in the placebo arm), and it was increased in Asian patients [76].

Although ocrelizumab has been unsuccessful in one clinical trial in SLE, this negative result may be attributed to the use of concomitant MMF. It has also been trialed in relapsing and remitting multiple sclerosis with only 3 of 55 
patients experiencing significant adverse events. The treatment was associated with a reduction in neurological lesions on magnetic resonance imaging (MRI) [78]. It remains possible that this drug can still be used in SLE pending additional trials.

\section{Veltuzumab}

\section{Mechanism of Action and Dosage}

Veltuzumab is a second generation humanised anti CD20 monoclonal antibody with a SC formulation, developed for the treatment of refractory pemphigus vulgaris and hematologic malignancies [79, 80]. A case report showed improved serological outcome with treatment with veltuzumab in a lupus patient who developed anti - drug antibodies (HACA) to rituximab [81]. The role of veltuzumab in SLE has yet to be clearly determined but may be used where rituximab is ineffective or there is "resistance" as seen in patients with non-Hodgkin lymphoma (NHL) [82].

\section{Bispecific Monoclonal Antibodies}

Recent laboratory studies suggested that the use of bispecific antibodies (anti CD22/CD20) might be effective in the treatment of lupus, as they were associated with increased trogocytosis. Trogocytosis is a process whereby lymphocytes conjugated with APC extract surface molecules from APCs and express them on their own surface in vitro, resulting in decreased levels of B cell surface markers associated with considerably less B cell depletion and therefore less risk of severe immunosuppression [83].

\section{Epratuzumab}

\section{Mechanism of Action and Dosage}

CD22 is a B cell transmembrane glycoprotein that is found on mature B cells. Epratuzumab is an IgG1 monoclonal antibody against the CD22 molecule, which inhibits B cell receptor activation and leads to subsequent B cell apoptosis. The ALLEVIATE-1 and ALLEVIATE-2 randomised clinical trials (RCTs) proved that $360 \mathrm{mg} / \mathrm{m}^{2} \mathrm{IV}$ dose was more effective than the $720 \mathrm{mg} / \mathrm{m}^{2}$ IV dose as a steroid-sparing medication in patients with severe lupus. The responses correlated with improvements in health-related quality of life [84]. The EMBLEM study was an early phase II B study performed to determine the 
effective dose regimen in patients with moderate-severe lupus, which showed that patients receiving a total of $2400 \mathrm{mg}$ had significant improvement in the disease activity [85].

The phase III studies, EMBODY 1 and 2, enrolled SLE patients who received placebo or treatment with $2400 \mathrm{mg}$ of epratuzumab over four 12-week treatment cycles, administered as $600 \mathrm{mg}$ every week for four weeks or 1,200 mg every two weeks for four weeks. The primary endpoint of both studies (which was defined as the percentage of patients meeting treatment response criteria at week 48 according to the British Isles Lupus Assessment Group (BILAG) - based Combined Lupus Assessment - BICLA) was not met and the research program was discontinued. BICLA, like the SRI (SLE responder index) system, requires patients to meet response criteria across three assessment tools: the BILAG-2004 index, SLEDAI index (SLE- disease activity index) and a physician's global assessment (PGA).

Epratuzumab is considered to reduce on average only $35 \%$ of circulating B cells in patients, and has minimal antibody and complement-dependent cellular cytotoxicity (when evaluated in vitro), and it was hypothesized that its therapeutic activity may not result completely from B cell depletion [83]. However, this was not translated in clinical benefits.

\section{Side Effect Profile}

Epratuzumab has been used in the treatment of both SLE and Sjögren's syndrome [85-87]. The drug has been proven to reduce BILAG scores as well as neuropsychiatric (62.5\%), muco-cutaneous (21.9\%) and musculoskeletal symptoms (32\%) compared to placebo [85].

The common side effects included infusion reaction, upper respiratory tract infections (URTI's), fever, headache, nausea and dizziness. A small proportion of patients developed human antidrug antibodies (HAHA). In contrast to rituximab, no severe decrease in the Ig levels was noted and this may be in relation to a partial depletion of $\mathrm{B}$ cells.

\section{Anti B Cell Activating Factors}

1. Belimumab

2. Tabalumab

3. Atacicept 


\section{Belimumab}

\section{Mechanism of Action and Dosage}

This is a monoclonal humanised Ig which binds to the BLyS protein. It is a transmembrane protein expressed by $\mathrm{T}$ cells, dendritic cells and neutrophils. The BlyS protein binds to 3 receptors on the $\mathrm{B}$ cell surface: the $\mathrm{B}$ cell maturation antigen (BMCA), BAFF-receptor (BR3, BAFF-R) and a transmembrane activator and calcium modulating ligand interactor (TACI); via these receptors it has a role is in B cell differentiation, Ig production and levels of disease activity [88]. Patients with SLE have high levels of BlyS, therefore binding of the BlyS protein leads to decrease B cell activation, maturation and antibody production. The dose used in lupus clinical trials was $10 \mathrm{mg} / \mathrm{kg}$ IV every 2 weeks for 6 weeks and thereafter monthly.

\section{Efficacy and Side Effect Profile}

Belimumab is considered effective in patient with non-renal and noncerebral SLE. FDA has approved it for mild to moderate SLE for those with skin and joint disease. It is not approved for active renal lupus or cerebral lupus. BLISS 52 and BLISS 76 studies have shown efficacy at 52 and 76 weeks [89]. BLISS 52 was carried out in countries from Central and Eastern Europe, AsiaPacific, and Latin America. At 52 weeks, there was a 58\% patients who had been treated with $10 \mathrm{~m} / \mathrm{kg}$ of belimumab met the primary outcome, which was the SRI response rate $(\mathrm{P}=0.017)$. SRI comprises criteria from three different internationally validated indices, SELENA-SLEDAI, PGA and BILAG 2004. BLISS 76 was a clinical trial which included patients from North America, and Western and Central Europe. Similarly, at 52 weeks $43 \%$ of patients treated with $10 \mathrm{mg} / \mathrm{kg}$ of belimumab met a similar primary outcome $(\mathrm{p}<0.02)$. The 52 week response was not maintained at 76 weeks. The results of these large clinical trials suggested that improvement of disease control is more likely in patients with low $\mathrm{C} 3$ and high dsDNA levels [90]. A pooled post-hoc analysis of the combined phase III studies suggested a possible benefit in lupus nephritis as

well [91]. Belimumab was associated with improvement of disease activity, reduced flares, decrease in dsDNA levels and low rate of side effects and it is currently licensed for use in non-renal lupus patients. The one drawback of belimumab is the delay onset of action and therefore not ideal for an acute flare treatment. It can take up to 6 months to achieve $70 \%$ B cell depletion. Common side effects included nausea, diarrhoea, headaches and URTIs, but their frequency was low. The rates of patients experiencing adverse events, as 
assessed from pooled data from one phase II and two phase III RCTs were $16.6 \%, 19.5 \%, 13.5 \%$, and $18.0 \%$ with placebo, and belimumab 1,4 , and 10 $\mathrm{mg} / \mathrm{kg}$, respectively [92]. There was also evidence of low rate of serious infusion reactions (including hypersensitivity reactions) occurring at a lower frequency that $1 \%$ in both placebo and active medication patient groups [92]. The side effect profile is not dose dependent. There is one case report of a severe delayed anaphylactic reaction which was fatal [92].

\section{Tabalumab}

\section{Mechanism of Action and Dosage}

BLyS, also known as BAFF, belongs to the TNF family. It is expressed by multiple cells including macrophages, monocytes, neutrophils and dendritic cells. BLys/BAFF binds to 3 receptors called BR3, thus affecting B cell lineage. TACI receptor is found on T cells and marginal zone B cells. BCMA (B cell maturation antigen) receptor is found on plasma cells. Activation of these receptors leads to auto-antibody production, increase in B cells and possibly potentiate malignancies [93].

In contrast to belimumab, tabalumab is an anti BAFF monoclonal antibody, which targets both membrane bound and soluble BAFF, currently used in RA [94]. The ILLUMINATE-1 study, a phase III RCT of tabalumab in patients with SLE, used the following dose regimen: $240 \mathrm{mg}$ SC loading dose, followed by $120 \mathrm{mg}$ every 2 weeks or 4 weeks in combination with traditional SLE treatments. The primary endpoint was the proportion of patients achieving an SLE Responder Index 5 (SRI-5) response at week 52. The SRI-5 is a composite endpoint defined as $\geq 5$ point improvement (reduction) in SELENA-SLEDAI score, no new BILAG 2004 index score of A or no more than one new BILAG $B$ score, and no worsening (increase $\geq 0.3$ points from baseline) in PGA [95]. The study did not meet the primary endpoint. Similarly, no difference in the secondary outcomes (which included time to first severe SLE flare on the SELENA-SLEDAI Flare Index, proportion of patients with reduction in corticosteroid dose by $\geq 25 \%$ to $\leq 7.5 \mathrm{mg} /$ day prednisone (or equivalent) for $\geq 3$ consecutive months from weeks 24 through 52, and change from baseline on the Brief Fatigue Inventory at week 52), was found between the active and placebo groups. However, in a sensitivity analysis which did not exclude the patients who decreased antimalarial, steroid or immunosuppressant therapy, SRI-5 response was achieved with tabalumab $120 \mathrm{mg}$ every 4 weeks (37.0\% vs $29.8 \%$ placebo; $\mathrm{p}=0.021$ ), suggesting a potential for this biologic agent to be effective in selected categories of lupus patients [95]. Furthermore, the ILLUMINATE-2 
study, which was set up in a broadly similar way to ILLUMINATE-1, but not excluding these patients whose concomitant medications were reduced, did not meet its primary endpoint. Unfortunately, despite the encouraging results, EliLilly have terminated the tabalumab program in lupus.

\section{Efficacy and Side Effect Profile}

The side-effects noted from the initial RA trials include infections and injection site reactions [96]. The most common infections included URTI and urinary tract infections (UTIs). Severe adverse events were also noted, such as myocardial infarct, discitis, osteomyelitis, breast cancer, cerebrovascular accident and pulmonary fibrosis $[96,97]$. The treatment with tabalumab was associated with slight increase in the incidence of depression and suicidality compared to placebo in the ILLUMINATE-1 study, but these side-effects were uncommon [98]. The incidence of serious infections and severe infections were similar in the tabalumab and placebo groups in SLE patients [95].

\section{Atacicept}

\section{Mechanism of Action and Dosage}

This novel agent inhibits both BLyS and APRIL in B cells, affecting B cells ranging from immature to mature. It is a TACI-Ig fusion receptor protein [99]. As described above, by inhibiting BlyS and APRIL it causes a reduction in B cell proliferation, IFN $\gamma$ and Ig production [100]. The doses used in the phase II/III RCT in lupus were either $75 \mathrm{mg}$ or $150 \mathrm{mg}$ atacicept SC biweekly for 4 weeks and then weekly versus placebo [101].

\section{Efficacy and Side Effect Profile}

In the APRIL-SLE phase II RCT, the $150 \mathrm{mg}$ atacicept arm was terminated early due to two fatal infections [101]. Despite this, a post-hoc analysis of atacicept $150 \mathrm{mg}$ has shown that this dose regimen reduced the incidence of flares and time to first flare compared to placebo (flare rate $37 \%$ vs. $54 \%$, odds ratio $-\mathrm{OR}=1.15(0.73-1.8)$, and time to flare $\mathrm{HR}=0.56, \mathrm{P}=0.009)$ [102]. There was no difference between atacicept $75 \mathrm{mg}$ and placebo. The clinical response was accompanied by decrease in B cells, Ig levels and increase in complement levels. The $75 \mathrm{mg}$ arm failed to meet the primary endpoint, defined as a significant decrease in the proportion of patients experiencing at least one flare of BILAG A or B [101].

The main safety concern regarding atacicept is that of potential increased incidence of hypogammaglobulinaemia and therefore, risk of infection. A study 
in patients with lupus nephritis was terminated after the enrolment of only 6 patients because of the severe decreased in the level of Ig [103]. A closer look at the concomitant medication, showed that these patients' hypogammaglobulinaemia developed when the patients were given MMF before they were treated with atacicept [104]. It was hypothesised that targeting APRIL in autoimmune disease might be associated with significant risk of toxicity [105]. Further phase II/III clinical trials of atacicept in lupus are currently undergoing (ADDRESS II) and should be able to provide additional information about the safety profile of this biologic agent. Apart from the two deaths encountered in the $150 \mathrm{mg}$ atacicept group in the APRIL-SLE trial, the proportion of the serious infections was not statistically significantly different between the $75 \mathrm{mg}$ atacicept arm when compared to placebo [101]. Furthermore, the death and injection rates were similar to those reported in the belimumab studies. The most common infections encountered included haemophilus influenzae pneumonia, legionella pneumonia and bacillus bacteraemia. Preclinical studies showed an increase in liver transaminases [101].

\section{Blisibimod}

\section{Mechanism of Action and Dosage}

Blisibimod is a fusion protein consisting of four BAFF binding domains fused to the $\mathrm{Fc}$ region of a human antibody, which acts as a selective antagonist of BAFF. Blisibimod selectively inhibits both soluble and membrane-bound BAFF.

\section{Efficacy and Side Effect Profile}

The efficacy and safety of blisibimod in subjects with SLE was investigated in a phase II RCT, PEARL-SC study, which found that the highest tested dose of $200 \mathrm{mg}$ blisibimod administered SC once weekly was associated with increased SRI-5 response rates, but without reaching statistical significance when compared with placebo. The treatment was more effective in patients with SELENA-SLEDAI improvement of $\geq 8$, and in a subgroup of patients with severe disease (SELENA-SLEDAI $\geq 10$ ) [106].

Blisibimod was associated with a decrease in the number of naïve $B$ cells (24-76\%) and a transient relative increase in the memory B cell compartment in the phase 1 studies [107]. It was also associated with significant decrease of dsDNA, increase in the complement $\mathrm{C} 3$ and $\mathrm{C} 4$, and reductions in serum B cell levels in the PEARL-SC study [106]. Blisibimod is currently being tested in a 
phase III study for SLE, CHABLIS-SC1, and a phase II study, BRIGHT-SC, for IgA nephropathy.

The treatment with blisibimod was safe, as the incidence of serious sideeffects was similar to the placebo arm. Injection site reactions were reported more frequently with blisibimod compared with placebo, but they were mild (erythema) [106]. Taking into consideration this treatment's serological benefits in SLE patients and acceptable safety profile, the results of the phase III study are awaited with interest as if proven more effective than belimumab, the treatment has a good chance to be the next licensed biologic treatment for lupus.

\section{Anti-Interferon Alpha (IFNa)}

1. Sifalimumab

2. Rontalizumab

3. Anifrolumab

\section{Mechanism of Action}

Sifalimumab and rontalizumab are anti-IFN $\alpha$ monoclonal antibodies. An increase in BAFF occurs via signalling of INF $\alpha$. The signalling pathway is activated by the stimulation of the IFN-1 receptor. In SLE pathogenesis there is activation of type 1 IFN, which is associated with lupus nephritis [108, 109]. Neutralisation of IFN $\alpha$ will lead to a reduction of inflammation by a reduction in BAFF levels, mature B cells, antibody production and T cell activation [110, $111]$.

\section{Sifalimumab}

\section{Dosage}

An optimal dose is yet to be confirmed as trials are currently underway. The phase I RCT in lupus used the following doses: $0.3,1,3,10$ or $30 \mathrm{mg} / \mathrm{kg}$ as a single IV administration [112]. The results of a promising phase II RCT of Sifalimumab in SLE were presented at the 2014 American College of Rheumatology (ACR) annual meeting [113].

The patients were randomised to receive monthly IV doses of sifalimumab at 200,600 , or $1200 \mathrm{mg}$ or placebo for 1 year based on their disease activity, IFN signatures and geographic region. The primary endpoint, defined as the percentage of patients achieving an SRI at day 365, was achieved in all the treatment active arms (sifalimumab 200, 600, and $1200 \mathrm{mg}$ doses were associated with $58.3,56.5,59.8 \%$, SRI response respectively, compared to 
$45.4 \%$ in the placebo group). Surprisingly, there were no significant changes of the dsDNA or complement levels despite the good response to treatment [113].

Efficacy and Side Effect Profile

The results from the early phase clinical trials showed a reduction in SLE disease activity [108, 113], and phase 3 trials are currently underway. Sifalimumab is considered safe although there have been reports of increase incidence of herpes zoster infection. Other side effects typically include infusion reactions, nausea, URTIs, UTIs, headache and arthralgia [108, 114].

\section{Rontalizumab}

\section{Mechanism of Action and Dosage}

Rontalizumab has a similar mechanism of action as sifalimumab [109]. In an early phase, dose-escalation study, patients were enrolled into dose groups ranging from 0.3 to $10 \mathrm{mg} / \mathrm{kg}$, administered via IV or SC routes [115].

\section{Efficacy and Side Effect Profile}

A recent phase II studies with rontalizumab in lupus did not meet the criteria for efficacy, which were reduction in disease activity as assessed by the BILAG and SRI [116]. A phase I study showed a dose dependent decrease in the level of IFN $\alpha$, but no decrease in levels of dsDNA. The side effect profile was deemed similar to placebo although an increase in viral infections was noted $[115,116]$

\section{Anifrolumab}

\section{Mechanism of Action and Dosage}

Anifrolumab is a type I IFN receptor antagonist [117], which was recently tested in a phase II RCT in patients with SLE using two dose regimens: 300 and $1000 \mathrm{mg}$ IV anifrolumab, monthly administration (ACR abstract data, Merrill et al., 2015 in press).

\section{Efficacy and Side Effect Profile}

The primary endpoint of this phase II RCT of anifrolumab in patients with moderate to severe SLE was a composite SRI response at day 169 with sustained reduction of the steroid dose ( $<10 \mathrm{mg} /$ day dose maintained between days 85 and 169. Both treatment regimens ( 300 and $1000 \mathrm{mg}$ anifrolumab) improved patients' outcomes and reached the primary endpoint $(34.3 \%$ and $28.8 \%$ respectively, vs. $17.6 \%$ placebo). Steroid dose reduction ( $<7.5 \mathrm{mg}$ daily) at day 
365 was achieved by $26.6 \%$ patients in the placebo group vs. $56.4 \%$ in the 300 $\mathrm{mg}$ anifrolumab group $(\mathrm{p}=0.001)$ and $31.7 \%$ in the $1000 \mathrm{mg}$ anifrolumab arm $(\mathrm{p}=0.59)$.

\title{
Efficacy and Side Effect Profile
}

The treatment with anifrolumab was associated with similar serious adverse events than placebo. A higher incidence of influenza (most unconfirmed) and a dose-dependent increase in herpes zoster were reported in the anifrolumab treatment arms compared to placebo.

The results from previous clinical trials with monoclonal antibodies to IFN have shown encouraging results and further trials are ongoing.

\section{Blockade of T Cell Activation}

\begin{abstract}
Abatacept
Mechanism of Action and Dosage

This is a fusion protein which interferes with the co stimulatory interactions between $\mathrm{B}$ and $\mathrm{T}$ lymphocytes. Activated $\mathrm{T}$ cells express cytotoxic $\mathrm{T}$ lymphocyte-associated protein 4 (CTLA4) which interacts with co-stimulatory receptor B7-1 (CD80). Abatacept is a combination of human $\mathrm{IgG}$ ( $\mathrm{Fc}$ portion) and CTLA-4. It therefore blocks stimulation of $\mathrm{B}$ cells leading to a reduction in antibody formation and immune response [118]. The doses used in lupus trials range from $10-30 \mathrm{mg} / \mathrm{kg}$ [119-123]

\section{Efficacy and Side Effect Profile}

Initial murine studies showed improvement in lupus nephritis, proteinuria and autoantibody titres but this has not yet translated into human studies. Phase II/III trials in lupus nephritis did not meet outcome measures, although when the same data were analysed using different criteria (LUNAR trial response criteria) there was a $20 \%$ response rate in the abatacept arm compared to placebo [119, 121].

The side effect profile is comparable to other biologics and is detailed in
\end{abstract} Table 1.

\section{IL6 Blockage}

1. Tocilizumab

2. Sirukumab 


\section{Tocilizumab}

\section{Mechanism of Action and Dosage}

In mouse models exogenous IL6 has been shown to increase autoantibody production and progression of lupus nephritis. By blocking IL6 there is a decrease in antibody formation, proteinuria and mortality. IL6 is released by intrinsic kidney cells and causes mesangial cell proliferation, activation of $\mathrm{T}$ and B cells and autoantibody secretion [124]. High IL6 levels are associated with SLE disease activity as well as dsDNA levels. By blocking IL6 there is a decrease in inflammation, B cell differentiation and autoantibody production [124]. Binding of IL6 to the receptor is prevented by tocilizumab, a fully humanised monoclonal antibody. It can bind to membrane bound or soluble IL6R [125]. The starting dose is $4 \mathrm{mg} / \mathrm{kg}$ monthly and this can be increased to $8 \mathrm{mg} / \mathrm{kg}$ monthly, pending clinical response [124].

\section{Efficacy and Side Effect Profile}

Although a well-established treatment in RA and systemic juvenile idiopathic arthritis (JIA) [126], its role in SLE is yet to be established. A phase I clinical trial in SLE proved the safety and efficacy of tocilizumab in lupus patients [124].

The side effect profile is thought to be less severe than with other biologic agents. URTIs and gastrointestinal infections are most common. The treatment with tocilizumab is associated with suppression of $\mathrm{C}$ - reactive protein (CRP), haematological abnormalities, non-melanoma skin tumours, and malignancies. Gastro-intestinal perforation has been reported in phase III trials in RA. Liver dysfunction and increased levels of LDL and total cholesterol has also been reported in clinical trials in RA $[127,128]$. In the only clinical trial in lupus, the treatment was associated with decreased neutrophil levels, but without major impact in increasing the risk of infections [124].

\section{Sirukumab}

Sirukumab is a humanised monoclonal antibody against IL6, similar to tocilizumab [129]. The results of a proof of concept study were reported at the ACR meeting in 2014 [130, 131]. Preliminary data suggested some improvement of the patient-outcome measures and transient improvement in 
clinical parameters [132]. The treatment with sirukumab was associated with a dose-dependent decrease in absolute neutrophil count and platelet count [133].

\section{FUtURE Treatment OPTIONS}

\section{Anti-Complement Therapies: Eculizumab}

Complement activation is strongly involved in the pathogenesis of SLE. The function of complement is to help clear immune complexes and a deficiency in this leads to the development of SLE. Eculizumab has been developed to inhibit terminal complement activation and maintain early complement function [134]. It is a monoclonal antibody against C5. By blocking C5 it prevents the formation of $\mathrm{C} 5 \mathrm{a}$ and $\mathrm{C} 5 \mathrm{~b}$ and the formation of the terminal membrane attack complex [135]. This drug is in phase 1 trials and limited data suggest a delay in the onset of proteinuria and improved outcomes in patients with hemolyticuremic syndrome after renal transplantation [136]. A recent case report also suggested clinical benefit in treating severe lupus nephritis in a paediatric patient [137].

\section{CONCLUSION}

The various clinical and laboratory abnormalities associated with SLE need tailored therapeutic interventions. Despite the large number of biologic treatments with potential efficacy for controlling different aspects of lupus disease, it is worth mentioning that only one biologic treatment, belimumab, was proven effective in large phase III clinical trials leading to the licensing of a new therapy for lupus. The strict inclusion criteria used in clinical trials suggest that even if shown effective, these treatments might only be useful for selected categories of SLE patients and the generalisation of the results from clinical trials is not indicated. However, despite the lack of efficacy in clinical trials, rituximab is widely believed to be effective in treating refractory SLE and it is currently widely used off license. Future research should lead to reconciliation between the clinical trial results and clinician expertise related to the use of biologic treatments for the benefit of SLE patients. 


\section{ACKNOWLEDGMENTS}

The authors would like to thank to Dr. Marwan Bukhari, Consultant Rheumatologist, Royal Lancaster Infirmary, Lancaster, UK (email: Marwan. Bukhari@mbht.nhs.uk) for reviewing the chapter.

\section{REFERENCES}

[1] S. C. Croca, T. Rodrigues, and D. A. Isenberg, "Assessment of a lupus nephritis cohort over a 30-year period," Rheumatology (Oxford), vol. 50, pp. 1424-30, Aug. 2011.

[2] P. Elfving, K. Puolakka, H. Kautiainen, L. J. Virta, T. Pohjolainen, and O. Kaipiainen-Seppanen, "Mortality and causes of death among incident cases of systemic lupus erythematosus in Finland 2000-2008," Lupus, vol. 23, pp. 1430-4, Nov. 2014.

[3] J. Trager and M. M. Ward, "Mortality and causes of death in systemic lupus erythematosus," Curr Opin Rheumatol, vol. 13, pp. 345-51, Sep. 2001.

[4] M. Abu-Shakra and V. Novack, "Mortality and multiple causes of death in systemic lupus erythematosus -- role of the death certificate," $J$ Rheumatol, vol. 39, pp. 458-60, Mar. 2012.

[5] Z. Liu and A. Davidson, "Taming lupus-a new understanding of pathogenesis is leading to clinical advances," Nat Med, vol. 18, pp. 87182, Jun. 2012.

[6] W. Su and M. P. Madaio, "Recent advances in the pathogenesis of lupus nephritis: autoantibodies and B cells," Semin Nephrol, vol. 23, pp. 564-8, Nov. 2003.

[7] L. C. Huber, S. Gay, O. Distler, and D. S. Pisetsky, "The effect of UVB on lupus skin: new light on the role of apoptosis in the pathogenesis of autoimmunity," Rheumatology (Oxford), vol. 45, pp. 500-1, May 2006.

[8] E. L. Greidinger, "Apoptosis in lupus pathogenesis," Front Biosci, vol. 6, pp. D1392-402, Nov. 12001.

[9] A. Kuhn, J. Wenzel, and H. Weyd, "Photosensitivity, apoptosis, and cytokines in the pathogenesis of lupus erythematosus: a critical review," Clin Rev Allergy Immunol, vol. 47, pp. 148-62, Oct. 2014. 
[10] L. E. Munoz, C. van Bavel, S. Franz, J. Berden, M. Herrmann, and J. van der Vlag, "Apoptosis in the pathogenesis of systemic lupus erythematosus," Lupus, vol. 17, pp. 371-5, May 2008.

[11] L. Reininger, M. L. Santiago, S. Takahashi, L. Fossati, and S. Izui, "T helper cell subsets in the pathogenesis of systemic lupus erythematosus," Ann Med Interne (Paris), vol. 147, pp. 467-71, 1996.

[12] X. Yang, B. Sun, H. Wang, C. Yin, X. Wang, and X. Ji, "Increased serum IL-10 in lupus patients promotes apoptosis of $\mathrm{T}$ cell subsets via the caspase 8 pathway initiated by Fas signaling," J Biomed Res, vol. 29, pp. 232-40, May 2015.

[13] J. C. Crispin, S. A. Apostolidis, M. I. Finnell, and G. C. Tsokos, "Induction of PP2A Bbeta, a regulator of IL-2 deprivation-induced T-cell apoptosis, is deficient in systemic lupus erythematosus," Proc Natl Acad Sci US, vol. 108, pp. 12443-8, Jul. 262011.

[14] R. K. Dinesh, B. J. Skaggs, A. La Cava, B. H. Hahn, and R. P. Singh, "CD8+ Tregs in lupus, autoimmunity, and beyond," Autoimmun Rev, vol. 9, pp. 560-8, Jun. 2010.

[15] C. G. Katsiari, S. N. Liossis, A. M. Dimopoulos, D. V. Charalambopoulo, M. Mavrikakis, and P. P. Sfikakis, "CD40L overexpression on T cells and monocytes from patients with systemic lupus erythematosus is resistant to calcineurin inhibition," Lupus, vol. 11, pp. 370-8, 2002.

[16] C. Toong, S. Adelstein, and T. G. Phan, "Clearing the complexity: immune complexes and their treatment in lupus nephritis," Int J Nephrol Renovasc Dis, vol. 4, pp. 17-28, 2011.

[17] A. Chang, S. G. Henderson, D. Brandt, N. Liu, R. Guttikonda, C. Hsieh et al., "In situ B cell-mediated immune responses and tubulointerstitial inflammation in human lupus nephritis," J Immunol, vol. 186, pp. 184960, Feb. 12011.

[18] M. Takao, "[Targeted therapy and progressive multifocal leukoencephalopathy (PML): PML in the era of monoclonal antibody therapies]," Brain Nerve, vol. 65, pp. 1363-74, Nov. 2013.

[19] G. Turchetti, J. Yazdany, I. Palla, E. Yelin, and M. Mosca, "Systemic lupus erythematosus and the economic perspective: a systematic literature review and points to consider," Clin Exp Rheumatol, vol. 30, pp. S11622, Jul.-Aug. 2012.

[20] J. Cho, S. Chang, N. Shin, B. Choi, H. Oh, M. Yoon et al., "Costs of illness and quality of life in patients with systemic lupus erythematosus in South Korea," Lupus, vol. 23, pp. 949-957, Feb. 212014. 
[21] A. E. Clarke, M. B. Urowitz, N. Monga, and J. G. Hanly, "Costs associated with severe and nonsevere systemic lupus erythematosus in Canada," Arthritis Care Res (Hoboken), vol. 67, pp. 431-6, Mar. 2015.

[22] D. E. Furst, A. Clarke, A. W. Fernandes, T. Bancroft, K. Gajria, W. Greth et al., "Resource utilization and direct medical costs in adult systemic lupus erythematosus patients from a commercially insured population," Lupus, vol. 22, pp. 268-78, Mar. 2013.

[23] P. Panopalis, J. Yazdany, J. Z. Gillis, L. Julian, L. Trupin, A. O. Hersh et al., "Health care costs and costs associated with changes in work productivity among persons with systemic lupus erythematosus," Arthritis Rheum, vol. 59, pp. 1788-95, Dec. 152008.

[24] P. Panopalis, M. Petri, S. Manzi, D. A. Isenberg, C. Gordon, J. L. Senecal et al., "The systemic lupus erythematosus Tri-Nation study: cumulative indirect costs," Arthritis Rheum, vol. 57, pp. 64-70, Feb. 152007.

[25] G. Gironimi, A. E. Clarke, V. H. Hamilton, D. S. Danoff, D. A. Bloch, J. F. Fries et al., "Why health care costs more in the US: comparing health care expenditures between systemic lupus erythematosus patients in Stanford and Montreal," Arthritis Rheum, vol. 39, pp. 979-87, Jun. 1996.

[26] N. Sutcliffe, A. E. Clarke, R. Taylor, C. Frost, and D. A. Isenberg, "Total costs and predictors of costs in patients with systemic lupus erythematosus," Rheumatology (Oxford), vol. 40, pp. 37-47, Jan. 2001.

[27] M. M. Ward, "Access to care and the incidence of endstage renal disease due to systemic lupus erythematosus," J Rheumatol, vol. 37, pp. 1158-63, Jun. 2010.

[28] E. M. Williams, K. Ortiz, M. Flournoy-Floyd, L. Bruner, and D. Kamen, "Systemic lupus erythematosus observations of travel burden: A qualitative inquiry," Int J Rheum Dis, Jul. 142015.

[29] A. Lateef, M. Lahiri, G. G. Teng, and S. Vasoo, "Use of rituximab in the treatment of refractory systemic lupus erythematosus: Singapore experience," Lupus, vol. 19, pp. 765-70, May 2010.

[30] A. M. Ryan, S. A. Sokolowski, C. K. Ng, N. Shirai, M. Collinge, A. C. Shen et al., "Comparative nonclinical assessments of the proposed biosimilar PF-05280586 and rituximab (MabThera(R))," Toxicol Pathol, vol. 42, pp. 1069-81, Oct. 2014.

[31] A. da Silva, U. Kronthaler, V. Koppenburg, M. Fink, I. Meyer, A. Papandrikopoulou et al., "Target-directed development and preclinical characterization of the proposed biosimilar rituximab GP2013," Leuk Lymphoma, vol. 55, pp. 1609-17, Jul. 2014. 
[32] M. Petri, S. Perez-Gutthann, J. C. Longenecker, and M. Hochberg, "Morbidity of systemic lupus erythematosus: role of race and socioeconomic status," Am J Med, vol. 91, pp. 345-53, Oct. 1991.

[33] A. Pons-Estel, L. J. Catoggio, M. H. Cardiel, E. R. Soriano, S. Gentiletti, A. R. Villa et al., "The GLADEL multinational Latin American prospective inception cohort of 1,214 patients with systemic lupus erythematosus: ethnic and disease heterogeneity among 'Hispanics,' “ Medicine (Baltimore), vol. 83, pp. 1-17, Jan. 2004.

[34] L. C. Plantinga, C. Drenkard, R. E. Patzer, M. Klein, M. R. Kramer, S. Pastan et al., "Sociodemographic and geographic predictors of quality of care in United States patients with end-stage renal disease due to lupus nephritis," Arthritis Rheumatol, vol. 67, pp. 761-72, Mar. 2015.

[35] D. L. Horowitz and R. Furie, "Belimumab is approved by the FDA: what more do we need to know to optimize decision making?" Curr Rheumatol Rep, vol. 14, pp. 318-23, Aug. 2012.

[36] J. Harris, "QALYfying the value of life," J Med Ethics, vol. 13, pp. 11723, Sep. 1987.

[37] G. J. Weiner, "Rituximab: mechanism of action," Semin Hematol, vol. 47, pp. 115-23, Apr. 2010.

[38] D. Albert, J. Dunham, S. Khan, J. Stansberry, S. Kolasinski, D. Tsai et al., "Variability in the biological response to anti-CD20 B cell depletion in systemic lupus erythaematosus," Ann Rheum Dis, vol. 67, pp. 1724-31, Dec. 2008.

[39] D. G. Maloney, "Mechanism of action of rituximab," Anticancer Drugs, vol. 12 Suppl. 2, pp. S1-4, Jun. 2001.

[40] B. Bonavida, "Rituximab-induced inhibition of antiapoptotic cell survival pathways: implications in chemo/immunoresistance, rituximab unresponsiveness, prognostic and novel therapeutic interventions," Oncogene, vol. 26, pp. 3629-36, May 282007.

[41] M. J. Leandro, G. Cambridge, J. C. Edwards, M. R. Ehrenstein, and D. A. Isenberg, "B cell depletion in the treatment of patients with systemic lupus erythematosus: a longitudinal analysis of 24 patients," Rheumatology (Oxford), vol. 44, pp. 1542-5, Dec. 2005.

[42] J. Merrill, J. Buyon, R. Furie, K. Latinis, C. Gordon, H. J. Hsieh et al., "Assessment of flares in lupus patients enrolled in a phase II/III study of rituximab (EXPLORER)," Lupus, vol. 20, pp. 709-16, Jun. 2011.

[43] B. H. Rovin, R. Furie, K. Latinis, R. J. Looney, F. C. Fervenza, J. Sanchez-Guerrero et al., "Efficacy and safety of rituximab in patients with 
active proliferative lupus nephritis: the Lupus Nephritis Assessment with Rituximab study," Arthritis Rheum, vol. 64, pp. 1215-26, Apr. 2012.

[44] L. Iaccarino, E. Bartoloni, L. Carli, F. Ceccarelli, F. Conti, S. De Vita et al., "Efficacy and safety of off-label use of rituximab in refractory lupus: data from the Italian Multicentre Registry," Clin Exp Rheumatol, vol. 33, pp. 449-56, Jul.-Aug. 2015.

[45] R. A. Hickman, R. Hira-Kazal, C. S. Yee, V. Toescu, and C. Gordon, "The efficacy and safety of rituximab in a chart review study of 15 patients with systemic lupus erythematosus," Clin Rheumatol, vol. 34, pp. 263-71, Feb. 2015.

[46] V. Reddy, D. Jayne, D. Close, and D. Isenberg, "B cell depletion in SLE: clinical and trial experience with rituximab and ocrelizumab and implications for study design," Arthritis Res Ther, vol. 15 Suppl. 1, p. S2, 2013.

[47] M. B. Condon, D. Ashby, R. J. Pepper, H. T. Cook, J. B. Levy, M. Griffith et al., "Prospective observational single-centre cohort study to evaluate the effectiveness of treating lupus nephritis with rituximab and mycophenolate mofetil but no oral steroids," Ann Rheum Dis, vol. 72, pp. 1280-6, Aug. 2013.

[48] A. N. Ezeonyeji and D. A. Isenberg, "Early treatment with rituximab in newly diagnosed systemic lupus erythematosus patients: a steroid-sparing regimen," Rheumatology (Oxford), vol. 51, pp. 476-81, Mar. 2012.

[49] J. E. Montoya, H. G. Luna, N. G. Vergara, J. R. Amparo, and G. R. CristalLuna, "Incidence of infusion-related reaction to monoclonal antibody rituximab: a national kidney and transplant institute experience," Ann Acad Med Singapore, vol. 41, pp. 125-6, Mar. 2012.

[50] Y. Pehlivan, B. Kisacik, V. K. Bosnak, and A. M. Onat, "Rituximab seems to be a safer alternative in patients with active rheumatoid arthritis with tuberculosis," BMJ Case Rep, vol. 2013, 2013.

[51] M. L. Burr, A. P. Malaviya, J. H. Gaston, A. J. Carmichael, and A. J. Ostor, "Rituximab in rheumatoid arthritis following anti-TNF-associated tuberculosis," Rheumatology (Oxford), vol. 47, pp. 738-9, May 2008.

[52] Y. X. Koo, D. S. Tan, I. B. Tan, M. Tao, and S. T. Lim, "Hepatitis B virus reactivation in a patient with resolved hepatitis $\mathrm{B}$ virus infection receiving maintenance rituximab for malignant B cell lymphoma," Ann Intern Med, vol. 150, pp. 655-6, May 52009.

[53] B. Terrier, D. Saadoun, D. Sene, J. Sellam, L. Perard, B. Coppere et al., "Efficacy and tolerability of rituximab with or without PEGylated interferon alfa- $2 \mathrm{~b}$ plus ribavirin in severe hepatitis $\mathrm{C}$ virus-related 
vasculitis: a long-term followup study of thirty-two patients," Arthritis Rheum, vol. 60, pp. 2531-40, Aug. 2009.

[54] C. Rodriguez-Escalera and A. Fernandez-Nebro, "The use of rituximab to treat a patient with ankylosing spondylitis and hepatitis B," Rheumatology (Oxford), vol. 47, pp. 1732-3, Nov. 2008.

[55] Y. H. Ahn, H. G. Kang, J. M. Lee, H. J. Choi, I. S. Ha, and H. I. Cheong, "Development of antirituximab antibodies in children with nephrotic syndrome," Pediatr Nephrol, vol. 29, pp. 1461-4, Aug. 2014.

[56] A. Vultaggio, E. Maggi, and A. Matucci, "Immediate adverse reactions to biologicals: from pathogenic mechanisms to prophylactic management," Curr Opin Allergy Clin Immunol, vol. 11, pp. 262-8, Jun. 2011.

[57] G. Cambridge, D. A. Isenberg, J. C. Edwards, M. J. Leandro, T. S. Migone, M. Teodorescu et al., "B cell depletion therapy in systemic lupus erythematosus: relationships among serum B lymphocyte stimulator levels, autoantibody profile and clinical response," Ann Rheum Dis, vol. 67, pp. 1011-6, Jul. 2008.

[58] A. Podolskaya, M. Stadermann, C. Pilkington, S. D. Marks, and K. Tullus, "B cell depletion therapy for 19 patients with refractory systemic lupus erythematosus," Arch Dis Child, vol. 93, pp. 401-6, May 2008.

[59] S. S. Dias, V. Rodriguez-Garcia, H. Nguyen, C. Pericleous, and D. Isenberg, "Longer duration of B cell depletion is associated with better outcome," Rheumatology (Oxford), vol. 54, pp. 1876-81, Oct. 2015.

[60] J. H. Anolik, J. Barnard, T. Owen, B. Zheng, S. Kemshetti, R. J. Looney et al., "Delayed memory B cell recovery in peripheral blood and lymphoid tissue in systemic lupus erythematosus after B cell depletion therapy," Arthritis Rheum, vol. 56, pp. 3044-56, Sep. 2007.

[61] I. de la Torre, M. J. Leandro, J. C. Edwards, and G. Cambridge, "Baseline serum immunoglobulin levels in patients with rheumatoid arthritis: relationships with clinical parameters and with B cell dynamics following rituximab," Clin Exp Rheumatol, vol. 30, pp. 554-60, Jul.-Aug. 2012.

[62] M. Heusele, P. Clerson, B. Guery, M. Lambert, D. Launay, G. Lefevre et al., "Risk factors for severe bacterial infections in patients with systemic autoimmune diseases receiving rituximab," Clin Rheumatol, vol. 33, pp. 799-805, Jun. 2014.

[63] C. Diaz-Lagares, S. Croca, S. Sangle, E. M. Vital, F. Catapano, A. Martinez-Berriotxoa et al., "Efficacy of rituximab in 164 patients with biopsy-proven lupus nephritis: pooled data from European cohorts," Autoimmun Rev, vol. 11, pp. 357-64, Mar. 2012. 
[64] S. C. Hofmann, M. J. Leandro, S. D. Morris, and D. A. Isenberg, "Effects of rituximab-based B cell depletion therapy on skin manifestations of lupus erythematosus--report of 17 cases and review of the literature," Lupus, vol. 22, pp. 932-9, Aug. 2013.

[65] H. Beckwith and L. Lightstone, "Rituximab in systemic lupus erythematosus and lupus nephritis," Nephron Clin Pract, vol. 128, pp. 250-4, 2014.

[66] S. O'Brien and A. Osterborg, "Ofatumumab: a new CD20 monoclonal antibody therapy for B cell chronic lymphocytic leukemia," Clin Lymphoma Myeloma Leuk, vol. 10, pp. 361-8, Oct. 2010.

[67] G. Nightingale, "Ofatumumab: a novel anti-CD20 monoclonal antibody for treatment of refractory chronic lymphocytic leukemia," Ann Pharmacother, vol. 45, pp. 1248-55, Oct. 2011.

[68] M. Hoyle, L. Crathorne, R. Garside, and C. Hyde, "Ofatumumab for the treatment of chronic lymphocytic leukaemia in patients who are refractory to fludarabine and alemtuzumab: a critique of the submission from GSK," Health Technol Assess, vol. 15 Suppl. 1, pp. 61-7, May 2011.

[69] P. C. Taylor, E. Quattrocchi, S. Mallett, R. Kurrasch, J. Petersen, and D. J. Chang, "Ofatumumab, a fully human anti-CD20 monoclonal antibody, in biological-naïve, rheumatoid arthritis patients with an inadequate response to methotrexate: a randomised, double-blind, placebo-controlled clinical trial," Ann Rheum Dis, vol. 70, pp. 2119-25, Dec. 2011.

[70] R. Kurrasch, J. C. Brown, M. Chu, J. Craigen, P. Overend, B. Patel et al., "Subcutaneously administered ofatumumab in rheumatoid arthritis: a phase I/II study of safety, tolerability, pharmacokinetics, and pharmacodynamics," J Rheumatol, vol. 40, pp. 1089-96, Jul. 2013.

[71] M. Ostergaard, B. Baslund, W. Rigby, B. Rojkovich, C. Jorgensen, P. T. Dawes et al., "Ofatumumab, a human anti-CD20 monoclonal antibody, for treatment of rheumatoid arthritis with an inadequate response to one or more disease-modifying antirheumatic drugs: results of a randomised, double-blind, placebo-controlled, phase I/II study," Arthritis Rheum, vol. 62, pp. 2227-38, Aug. 2010.

[72] H. Struemper, M. Sale, B. R. Patel, M. Ostergaard, A. Osterborg, W. G. Wierda et al., "Population pharmacokinetics of ofatumumab in patients with chronic lymphocytic leukemia, follicular lymphoma, and rheumatoid arthritis," J Clin Pharmacol, vol. 54, pp. 818-27, Jul. 2014.

[73] C. C. Thornton, N. Ambrose, and Y. Ioannou, "Ofatumumab: a novel treatment for severe systemic lupus erythematosus," Rheumatology (Oxford), vol. 54, pp. 559-60, Mar. 2015. 
[74] F. Morschhauser, P. Marlton, U. Vitolo, O. Linden, J. F. Seymour, M. Crump et al., "Results of a phase I/II study of ocrelizumab, a fully humanized anti-CD20 mAb, in patients with relapsed/refractory follicular lymphoma," Ann Oncol, vol. 21, pp. 1870-6, Sep. 2010.

[75] P. P. Tak, P. J. Mease, M. C. Genovese, J. Kremer, B. Haraoui, Y. Tanaka et al., "Safety and efficacy of ocrelizumab in patients with rheumatoid arthritis and an inadequate response to at least one tumor necrosis factor inhibitor: results of a forty-eight-week randomised, double-blind, placebo-controlled, parallel-group phase III trial," Arthritis Rheum, vol. 64, pp. 360-70, Feb. 2012.

[76] E. F. Mysler, A. J. Spindler, R. Guzman, M. Bijl, D. Jayne, R. A. Furie et al., "Efficacy and safety of ocrelizumab in active proliferative lupus nephritis: results from a randomised, double-blind, phase III study," Arthritis Rheum, vol. 65, pp. 2368-79, Sep. 2013.

[77] M. Ramos-Casals, I. Sanz, X. Bosch, J. H. Stone, and M. A. Khamashta, "B cell-depleting therapy in systemic lupus erythematosus," Am J Med, vol. 125, pp. 327-36, Apr. 2012.

[78] L. Kappos, D. Li, P. A. Calabresi, P. O’Connor, A. Bar-Or, F. Barkhof et al., "Ocrelizumab in relapsing-remitting multiple sclerosis: a phase 2, randomised, placebo-controlled, multicentre trial," Lancet, vol. 378, pp. 1779-87, Nov. 192011.

[79] R. M. Sharkey, H. Karacay, C. H. Chang, W. J. McBride, I. D. Horak, and D. M. Goldenberg, "Improved therapy of non-Hodgkin's lymphoma xenografts using radionuclides pretargeted with a new anti-CD20 bispecific antibody," Leukemia, vol. 19, pp. 1064-9, Jun. 2005.

[80] B. Godeau, "B cell depletion in immune thrombocytopenia," Semin Hematol, vol. 50 Suppl. 1, pp. S75-82, Jan. 2013.

[81] R. M. Faria and D. A. Isenberg, "Three different B cell depletion (antiCD20 monoclonal antibodies) treatments for severe resistant systemic lupus erythematosus," Lupus, vol. 19, pp. 1256-7, Sep. 2010.

[82] A. R. Rezvani and D. G. Maloney, "Rituximab resistance," Best Pract Res Clin Haematol, vol. 24, pp. 203-16, Jun. 2011.

[83] E. A. Rossi, C. H. Chang, and D. M. Goldenberg, "Anti-CD22/CD20 Bispecific antibody with enhanced trogocytosis for treatment of Lupus," PLoS One, vol. 9, p. e98315, 2014.

[84] V. Strand, M. Petri, K. Kalunian, C. Gordon, D. J. Wallace, K. Hobbs et al., "Epratuzumab for patients with moderate to severe flaring SLE: health-related quality of life outcomes and corticosteroid use in the 
randomised controlled ALLEVIATE trials and extension study SL0006," Rheumatology (Oxford), vol. 53, pp. 502-11, Mar. 2014.

[85] D. J. Wallace, K. Kalunian, M. A. Petri, V. Strand, F. A. Houssiau, M. Pike et al., "Efficacy and safety of epratuzumab in patients with moderate/severe active systemic lupus erythematosus: results from EMBLEM, a phase IIb, randomised, double-blind, placebo-controlled, multicentre study," Ann Rheum Dis, vol. 73, pp. 183-90, Jan. 2014.

[86] C. Daridon, D. Blassfeld, K. Reiter, H. E. Mei, C. Giesecke, D. M. Goldenberg et al., "Epratuzumab targeting of CD22 affects adhesion molecule expression and migration of B cells in systemic lupus erythematosus," Arthritis Res Ther, vol. 12, p. R204, 2010.

[87] S. D. Steinfeld, L. Tant, G. R. Burmester, N. K. Teoh, W. A. Wegener, D. M. Goldenberg et al., "Epratuzumab (humanised anti-CD22 antibody) in primary Sjogren's syndrome: an open-label phase I/II study," Arthritis Res Ther, vol. 8, p. R129, 2006.

[88] G. J. Dennis, "Belimumab: a BLyS-specific inhibitor for the treatment of systemic lupus erythematosus," Clin Pharmacol Ther, vol. 91, pp. 143-9, Jan. 2012.

[89] S. Manzi, J. Sanchez-Guerrero, J. T. Merrill, R. Furie, D. Gladman, S. V. Navarra et al., "Effects of belimumab, a B lymphocyte stimulator-specific inhibitor, on disease activity across multiple organ domains in patients with systemic lupus erythematosus: combined results from two phase III trials," Ann Rheum Dis, vol. 71, pp. 1833-8, Nov. 2012.

[90] R. F. van Vollenhoven, M. A. Petri, R. Cervera, D. A. Roth, B. N. Ji, C. S. Kleoudis et al., "Belimumab in the treatment of systemic lupus erythematosus: high disease activity predictors of response," Ann Rheum Dis, vol. 71, pp. 1343-9, Aug. 2012.

[91] M. A. Dooley, F. Houssiau, C. Aranow, D. P. D’Cruz, A. Askanase, D. A. Roth et al., "Effect of belimumab treatment on renal outcomes: results from the phase 3 belimumab clinical trials in patients with SLE," Lupus, vol. 22, pp. 63-72, Jan. 2013.

[92] D. J. Wallace, S. Navarra, M. A. Petri, A. Gallacher, M. Thomas, R. Furie et al., "Safety profile of belimumab: pooled data from placebo-controlled phase 2 and 3 studies in patients with systemic lupus erythematosus," Lupus, vol. 22, pp. 144-54, Feb. 2013.

[93] F. B. Vincent, D. Saulep-Easton, W. A. Figgett, K. A. Fairfax, and F. Mackay, "The BAFF/APRIL system: emerging functions beyond B cell biology and autoimmunity," Cytokine Growth Factor Rev, vol. 24, pp. 203-15, Jun. 2013. 
[94] M. C. Genovese, R. M. Fleischmann, M. Greenwald, J. Satterwhite, M. Veenhuizen, L. Xie et al., "Tabalumab, an anti-BAFF monoclonal antibody, in patients with active rheumatoid arthritis with an inadequate response to TNF inhibitors," Ann Rheum Dis, vol. 72, pp. 1461-8, Sep. 1 2013.

[95] D. A. Isenberg, M. Petri, K. Kalunian, Y. Tanaka, M. B. Urowitz, R. W. Hoffman et al., "Efficacy and safety of subcutaneous tabalumab in patients with systemic lupus erythematosus: results from ILLUMINATE1, a 52-week, phase III, multicentre, randomised, double-blind, placebocontrolled study," Ann Rheum Dis, Sep. 32015.

[96] J. S. Smolen, M. E. Weinblatt, D. van der Heijde, W. F. Rigby, R. van Vollenhoven, C. O. Bingham, $3^{\text {rd }}$ et al., "Efficacy and safety of tabalumab, an anti-B cell-activating factor monoclonal antibody, in patients with rheumatoid arthritis who had an inadequate response to methotrexate therapy: results from a phase III multicentre, randomised, double-blind study," Ann Rheum Dis, vol. 74, pp. 1567-70, Aug. 2015.

[97] M. C. Genovese, E. Lee, J. Satterwhite, M. Veenhuizen, D. Disch, P. Y. Berclaz et al., "A phase 2 dose-ranging study of subcutaneous tabalumab for the treatment of patients with active rheumatoid arthritis and an inadequate response to methotrexate," Ann Rheum Dis, vol. 72, pp. 145360, Sep. 12013.

[98] J. T. Merrill, R. F. van Vollenhoven, J. P. Buyon, R. A. Furie, W. Stohl, M. Morgan-Cox et al., "Efficacy and safety of subcutaneous tabalumab, a monoclonal antibody to B cell activating factor, in patients with systemic lupus erythematosus: results from ILLUMINATE-2, a 52-week, phase III, multicentre, randomised, double-blind, placebo-controlled study," Ann Rheum Dis, Aug. 202015.

[99] B. Gatto, "Atacicept, a homodimeric fusion protein for the potential treatment of diseases triggered by plasma cells," Curr Opin Investig Drugs, vol. 9, pp. 1216-27, Nov. 2008.

[100] R. J. Looney, "B cell-targeted therapies for systemic lupus erythematosus: an update on clinical trial data," Drugs, vol. 70, pp. 529-40, Mar. 262010.

[101] D. Isenberg, C. Gordon, D. Licu, S. Copt, C. P. Rossi, and D. Wofsy, "Efficacy and safety of atacicept for prevention of flares in patients with moderate-to-severe systemic lupus erythematosus (SLE): 52-week data (APRIL-SLE randomised trial)," Ann Rheum Dis, Jun. 202014.

[102] D. Isenberg, C. Gordon, D. Licu, S. Copt, C. P. Rossi, and D. Wofsy, "Efficacy and safety of atacicept for prevention of flares in patients with moderate-to-severe systemic lupus erythematosus (SLE): 52-week data 
(APRIL-SLE randomised trial)," Ann Rheum Dis, vol. 74, pp. 2006-15, Nov. 2015.

[103] E. M. Ginzler, S. Wax, A. Rajeswaran, S. Copt, J. Hillson, E. Ramos et al., "Atacicept in combination with MMF and corticosteroids in lupus nephritis: results of a prematurely terminated trial," Arthritis Res Ther, vol. 14, p. R33, 2012.

[104] E. Cogollo, M. A. Silva, and D. Isenberg, "Profile of atacicept and its potential in the treatment of systemic lupus erythematosus," Drug Des Devel Ther, vol. 9, pp. 1331-9, 2015.

[105] J. Morel and M. Hahne, "To target or not to target APRIL in systemic lupus erythematosus: that is the question!" Arthritis Res Ther, vol. 15, p. 107, 2013.

[106] R. A. Furie, G. Leon, M. Thomas, M. A. Petri, A. D. Chu, C. Hislop et al., "A phase 2, randomised, placebo-controlled clinical trial of blisibimod, an inhibitor of B cell activating factor, in patients with moderate-to-severe systemic lupus erythematosus, the PEARL-SC study," Ann Rheum Dis, vol. 74, pp. 1667-75, Sep. 2015.

[107] W. Stohl, J. T. Merrill, R. J. Looney, J. Buyon, D. J. Wallace, M. H. Weisman et al., "Treatment of systemic lupus erythematosus patients with the BAFF antagonist "peptibody" blisibimod (AMG 623/A-623): results from randomised, double-blind phase 1a and phase 1b trials," Arthritis Res Ther, vol. 17, p. 215, 2015.

[108] M. Petri, D. J. Wallace, A. Spindler, V. Chindalore, K. Kalunian, E. Mysler et al., "Sifalimumab, a human anti-interferon-alpha monoclonal antibody, in systemic lupus erythematosus: a phase I randomised, controlled, dose-escalation study," Arthritis Rheum, vol. 65, pp. 1011-21, Apr. 2013.

[109] A. Mathian, M. Hie, F. Cohen-Aubart, and Z. Amoura, "Targeting interferons in systemic lupus erythematosus: current and future prospects," Drugs, vol. 75, pp. 835-46, May 2015.

[110] R. Narwal, L. K. Roskos, and G. J. Robbie, "Population pharmacokinetics of sifalimumab, an investigational anti-interferon-alpha monoclonal antibody, in systemic lupus erythematosus," Clin Pharmacokinet, vol. 52, pp. 1017-27, Nov. 2013.

[111] B. R. Lauwerys, J. Ducreux, and F. A. Houssiau, "Type I interferon blockade in systemic lupus erythematosus: where do we stand?," Rheumatology (Oxford), vol. 53, pp. 1369-76, Aug. 2014.

[112] J. T. Merrill, D. J. Wallace, M. Petri, K. A. Kirou, Y. Yao, W. I. White et al., "Safety profile and clinical activity of sifalimumab, a fully human 
anti-interferon alpha monoclonal antibody, in systemic lupus erythematosus: a phase I, multicentre, double-blind randomised study," Ann Rheum Dis, vol. 70, pp. 1905-13, Nov. 2011.

[113] A. Mathian, M. Hie, F. Cohen-Aubart, and Z. Amoura, "Targeting Interferons in Systemic Lupus Erythematosus: Current and Future Prospects," Drugs, vol. 75, pp. 835-846, May 2015.

[114] B. W. Higgs, W. Zhu, C. Morehouse, W. I. White, P. Brohawn, X. Guo et al., "A phase $1 \mathrm{~b}$ clinical trial evaluating sifalimumab, an anti-IFN-alpha monoclonal antibody, shows target neutralisation of a type I IFN signature in blood of dermatomyositis and polymyositis patients," Ann Rheum Dis, vol. 73, pp. 256-62, Jan. 2014.

[115] J. M. McBride, J. Jiang, A. R. Abbas, A. Morimoto, J. Li, R. Maciuca et al., "Safety and pharmacodynamics of rontalizumab in patients with systemic lupus erythematosus: results of a phase I, placebo-controlled, double-blind, dose-escalation study," Arthritis Rheum, vol. 64, pp. 366676, Nov. 2012.

[116] K. C. Kalunian, J. T. Merrill, R. Maciuca, J. M. McBride, M. J. Townsend, X. Wei et al., "A Phase II study of the efficacy and safety of rontalizumab (rhuMAb interferon-alpha) in patients with systemic lupus erythematosus (ROSE)," Ann Rheum Dis, Jun. 2015.

[117] C. Morehouse, L. D. Chang, L. W. Wang, P. Brohawn, S. Ueda, G. Illei et al., "Target Modulation of a Type I Interferon (IFN) Gene Signature with Sifalimumab or Anifrolumab in Systemic Lupus Erythematosus (SLE) Patients in Two Open Label Phase 2 Japanese Trials," Arthritis and Rheumatology, vol. 66, pp. S313-S314, Oct. 2014.

[118] A. Y. Hoi and G. O. Littlejohn, "Abatacept in the treatment of lupus," Expert Opin Biol Ther, vol. 12, pp. 1399-406, Oct. 2012.

[119] J. T. Merrill, R. Burgos-Vargas, R. Westhovens, A. Chalmers, D. D'Cruz, D. J. Wallace et al., "The efficacy and safety of abatacept in patients with non-life-threatening manifestations of systemic lupus erythematosus: results of a twelve-month, multicenter, exploratory, phase IIb, randomised, double-blind, placebo-controlled trial," Arthritis Rheum, vol. 62, pp. 3077-87, Oct. 2010.

[120] D. Wofsy, J. L. Hillson, and B. Diamond, "Abatacept for lupus nephritis: alternative definitions of complete response support conflicting conclusions," Arthritis Rheum, vol. 64, pp. 3660-5, Nov. 2012.

[121] R. Furie, K. Nicholls, T. T. Cheng, F. Houssiau, R. Burgos-Vargas, S. L. Chen et al., "Efficacy and safety of abatacept in lupus nephritis: a twelve- 
month, randomised, double-blind study," Arthritis Rheumatol, vol. 66, pp. 379-89, Feb. 2014.

[122] J. I. Shin, S. J. Park, and M. A. Saleem, "The beneficial effect of abatacept in lupus nephritis may include stabilization of beta1 integrin activation in podocytes and Treg cell repopulation: comment on the article by Furie et al.," Arthritis Rheumatol, vol. 66, pp. 2913-4, Oct. 2014.

[123] "Treatment of lupus nephritis with abatacept: the Abatacept and Cyclophosphamide Combination Efficacy and Safety Study," Arthritis Rheumatol, vol. 66, pp. 3096-104, Nov. 2014.

[124] G. G. Illei, Y. Shirota, C. H. Yarboro, J. Daruwalla, E. Tackey, K. Takada et al., "Tocilizumab in systemic lupus erythematosus: data on safety, preliminary efficacy, and impact on circulating plasma cells from an open-label phase I dosage-escalation study," Arthritis Rheum, vol. 62, pp. 542-52, Feb. 2010.

[125] M. Suzuki, M. Hashizume, H. Yoshida, and M. Mihara, "Antiinflammatory mechanism of tocilizumab, a humanized anti-IL6R antibody: effect on the expression of chemokine and adhesion molecule," Rheumatol Int, vol. 30, pp. 309-15, Jan. 2010.

[126] D. Killock, "Rheumatoid arthritis: Tocilizumab is efficacious in active RA as little as 1 week after treatment," Nat Rev Rheumatol, vol. 7, p. 683, Dec. 2011.

[127] S. Yokota, T. Imagawa, M. Mori, T. Miyamae, Y. Aihara, S. Takei et al., "Efficacy and safety of tocilizumab in patients with systemic-onset juvenile idiopathic arthritis: a randomised, double-blind, placebocontrolled, withdrawal phase III trial," Lancet, vol. 371, pp. 998-1006, Mar. 222008.

[128] N. Nishimoto, N. Miyasaka, K. Yamamoto, S. Kawai, T. Takeuchi, and J. Azuma, "Long-term safety and efficacy of tocilizumab, an anti-IL6 receptor monoclonal antibody, in monotherapy, in patients with rheumatoid arthritis (the STREAM study): evidence of safety and efficacy in a 5-year extension study," Ann Rheum Dis, vol. 68, pp. 1580-4, Oct. 2009.

[129] Z. Xu, E. Bouman-Thio, C. Comisar, B. Frederick, B. Van Hartingsveldt, J. C. Marini et al., "Pharmacokinetics, pharmacodynamics and safety of a human anti-IL6 monoclonal antibody (sirukumab) in healthy subjects in a first-in-human study," Br J Clin Pharmacol, vol. 72, pp. 270-81, Aug. 2011.

[130] C. Aranow, R. van Vollenhoven, B. H. Rovin, C. Wagner, B. Zhou, R. Gordon et al., "A Phase 2, Multicenter, Randomised, Double-Blind, 
Placebo-Controlled, Proof-of-Concept Study to Evaluate the Efficacy and Safety of Sirukumab in Patients with Active Lupus Nephritis," Arthritis and Rheumatology, vol. 66, pp. S1239-S1239, Oct. 2014.

[131] R. van Vollenhoven, C. Aranow, B. Rovin, C. Wagner, B. Zhou, R. Gordon et al., "A Phase 2, Multicenter, Randomised, Double-Blind, Placebo-Controlled, Proof-of-Concept Study to Evaluate the Efficacy and Safety of Sirukumab in Patients with Active Lupus Nephritis," Ann Rheum Dis, vol. 73, pp. 78-78, Jun. 2014.

[132] U. Thanarajasingam and T. B. Niewold, "Sirukumab: a novel therapy for lupus nephritis?" Expert Opin Investig Drugs, vol. 23, pp. 1449-1455, Oct. 2014.

[133] U. Thanarajasingam and T. B. Niewold, "Sirukumab: a novel therapy for lupus nephritis?” Expert Opin Investig Drugs, vol. 23, pp. 1449-55, Oct. 2014.

[134] P. Hillmen, P. Muus, U. Duhrsen, A. M. Risitano, J. Schubert, L. Luzzatto et al., "Effect of the complement inhibitor eculizumab on thromboembolism in patients with paroxysmal nocturnal hemoglobinuria," Blood, vol. 110, pp. 4123-8, Dec. 12007.

[135] "Eculizumab: 5G1.1, h5G1.1, long-acting anti-C5 monoclonal antibody 5G1-1, long-acting anti-C5 monoclonal antibody 5G1.1," Drugs $R D$, vol. 8, pp. 61-8, 2007.

[136] C. F. Larrea, F. Cofan, F. Oppenheimer, J. M. Campistol, G. Escolar, and M. Lozano, "Efficacy of eculizumab in the treatment of recurrent atypical hemolytic-uremic syndrome after renal transplantation," Transplantation, vol. 89, pp. 903-4, Apr. 152010.

[137] R. Coppo, L. Peruzzi, A. Amore, S. Martino, L. Vergano, I. Lastauka et al., "Dramatic effects of eculizumab in a child with diffuse proliferative lupus nephritis resistant to conventional therapy," Pediatr Nephrol, vol. 30, pp. 167-72, Jan. 2015. 